\title{
Parental Consumption Decisions and Child Health During the Early French Fertility Decline, 1790-1914
}

\author{
DAVID R. WeIR
}

This article re-examines the secular improvement in human heights in France. Adult heights reflect consumption as children, so the distribution of resources between children and adults, determined primarily within households, should have influenced heights. The intrahousehold distribution of resources was influenced by the level of income and by the calorie demands of working adults. Results show that the early decline of marital fertility in France was accompanied by a small but significant increase in expenditures on child quality as measured by heights. Reductions in mortality, independent of the level of food intake, also contributed to improved heights.

B iological studies of human growth have established the general outlines of a production function for heights, which are now familiar to economic historians. ${ }^{1}$ Adult height is normally attained between the ages of 18 and 22, with the earlier ages being more typical of betternourished populations. The height attained reflects cumulative net nutrition over the preceding years: total nutrient intake, minus total nutrient expenditure on physical activity, minus nutrients lost due to disease (through either metabolic demands to fight disease or diseaseinduced failure to absorb nutrients consumed).

The best-established empirical relationship is that of mean height and mean per capita output. ${ }^{2}$ Clearly much of what is measured by mean per capita GNP (the construction of factories or government buildings, financial services, and so on) is only tangentially relevant to the net nutritional status of children under 20. GNP per capita is correlated with heights because the inputs to child nutrition that matter for heights tend to be correlated with total GNP. But which inputs? Although some historians have been careful to elaborate the many possible background

The Journal of Economic History, Vol. 53, No. 2 (June 1993). () The Economic History Association. All rights reserved. ISSN 0022-0507.

David R. Weir is Directeur de Recherche, Institut National de la Recherche Agronomique, 63 bd de Brandebourg, 94205 IVRY Cedex, France.

The author has benefited greatly from preliminary conversations with Robert Fogel, Duncan Thomas, Mark Thomas, and Kenneth Wachter, and from comments on a previous draft by Sheila Ryan Johannson and Richard Steckel. The research has been supported in part by the Sloan Foundation and the Social Science Faculty Research Fund at Yale University.

'Tanner, Fetus Into Man, and A History of the Study of Human Growth; Fogel, "Nutrition and the Decline in Mortality"; Steckel, "Stature and Living Standards"; Floud, Wachter, and Gregory, Height, Health and History; and Mokyr, "Economics, History, and Human Biology."

2 Steckel, "Height and Per Capita Income"; Brinkman, Drukker, and Slot, "Height and Income"; and van Meerten, "Développement économique et stature." 
influences on the several proximate determinants of heights, attention often collapses onto the simple link of real income to food intake to heights. ${ }^{3}$ Thus, heights come to be seen as a proxy for some general notion of standard of living, raising puzzles when they seem not to agree with other evidence, such as real wages. ${ }^{4}$

If we take seriously the notion of heights as a measure of net nutritional status, we must be alert to two other general possibilities. First, heights may be determined by factors other than food intake that move independently of GNP; second, the proportion of GNP devoted to things that matter for children's nutrition (whether food intake or other factors) is likely to vary systematically over time and between countries due to components like relative prices that ought to be of interest to economic historians.

The relationship between mean height and mean per capita output is affected by how the available nutritional resources are distributed within the population. The interhousehold distribution of income has received some attention from economic historians. ${ }^{5}$ However, the intergenerational distribution of nutritional resources within households has not received the same attention, despite its obvious importance. Height is fully determined during the years before adulthood, most of which are spent as a dependent child in a family. For any total family income, a change in the allocation between adults (whose heights are already determined) and children (whose final heights will be affected by their level of consumption) can have an effect on heights of the children's cohort. This allocation is determined by parents; thus, parental consumption choices must be a crucial mediator between mean per capita output and mean height.

It is in the consumption decisions of households that the history of heights intersects the history of fertility, and it is the uniquely early fertility decline in France that makes it a particularly important case for study. ${ }^{6}$ Resources devoted to children are an investment in what some economists call the "quality" of children. The interrelationship between fertility and heights is thus an element of the consumption trade-offs parents make between the quantity and quality of children. In our effort to understand the early French fertility decline, historical evidence on the interaction between quantity and quality can help discriminate between some general possibilities. In a Malthusian model

\footnotetext{
${ }^{3}$ See Steckel, "Stature and Living Standards," fig. 1, for an effort at a comprehensive specification.

${ }^{4}$ See the difficulties experienced by Floud, Wachter, and Gregory in reconciling all but the most long-term trends in their data on heights with what is known about British living standards (Height, Health and History, pp. 275-305).

5 Fogel, "New Sources and New Techniques"; Steckel, "Stature and Living Standards."

6 Weir, "Two Approaches to the Fertility Transition," shows that marital fertility began to decline rapidly in the 1790 s and declined more or less continuously until World War I. Since then, marital fertility has undergone pronounced long swings without any discernible trend.
} 
(in which income effects are all that matter), we would expect quantity and quality to increase together as income rose. Modern neoclassical models, however, emphasize the substitution of increased quality for decreased quantity during economic development because of increases in the returns to investing in children.

The trade-off between quality and quantity of children is not the only or even the most important one that parents must make. In determining the allocation of family nutritional resources, rational parents who care about the welfare of all the family members will distribute resources across family members so as to maximize their own notion of family welfare. This can lead to discrimination by sex, if feeding boys leads to higher returns in the form of valued work. ${ }^{7}$ A similar logic could apply between generations: in a context of generally poor nutrition, raising the consumption of adults can lead to higher labor productivity and therefore to higher family income. ${ }^{8}$ This may not be the case in a wellnourished population, which implies that exogenous improvements in earning capacity due to technological change or market expansion will have different consequences for child nutrition depending on the general level of nutrition. Changes in the nature of work that reduce the calories needed to produce a given income could also affect the interhousehold distribution.

\section{CONSCRIPTS, VOLUNTEERS, AND HEIGHT MEASUREMENT}

France provides the best data for the study of heights of any European country. The main source of height data after 1800 is the records of conscripts into the French armies. Prior to the Revolution of 1789, French armies were volunteer armies, like those of the rest of Europe. Conscription began with the first Revolutionary wars, but the data only become regular and reliable after 1815 . This article relies on aggregated frequency distributions of heights at the national and regional levels to estimate means and medians; the massive quantity of individual records remains largely untapped. ${ }^{9}$

Conscription records have distinct advantages over the records of volunteer services, which have been used for virtually all other historical studies. ${ }^{10}$ With some minor exceptions discussed in an appendix

\footnotetext{
${ }^{7}$ Rosenzweig and Schultz, "Market Opportunities."

${ }^{8}$ This is the basis for the large literature in development economics concerning "nutritional efficiency wages." See Behrman and Deolalikar, "Health and Nutrition"; and Strauss, "Does Better Nutrition Raise Farm Productivity?"'

${ }^{9}$ The aggregated data were published in an annual report, the Compte-rendu sur le recrutement de l'armée. Beginning with the recruitment class of 1873, the Annuaire Statistique also published the department-level data. A critical analysis of the data sources and a discussion of estimation methods developed to compensate for some minor problems before 1873 is contained in an unpublished appendix available on request from the author.

${ }^{10}$ This is the case for Britain (Floud, Wachter, and Gregory, Height, Health and History),
} 
available from the author, the French conscripts whose heights are reported were randomly drawn from the population in the most literal sense: they were selected by lottery from all the 20 -year-olds in the district. In volunteer services there are two selection processes at work, neither of which can be considered random: the demand of the recruiting services for men of certain heights (or other characteristics correlated with height), and the supply of potential recruits.

The statistical methods that have been developed to cope with selection problems depend crucially on the assumption that there is a range of heights (typically the upper tail of the distribution) in which selection effects do not operate. ${ }^{11}$ This works well when the recruiter's selection excludes persons below some minimum height. But if selection is continuous, in the sense that the probability of inclusion increases with height throughout the entire observed range, then the available estimators break down. Moreover, it is possible for the selected sample to closely resemble a Gaussian distribution, with a mean well above the mean of the whole population (and, typically, a smaller standard deviation). If the estimation methods do not fully eliminate the influence of selection, then changes over time in the strength of selection can appear as changes in the estimated height. For example, a democratization of entry into a highly elite school would appear as a deterioration in height. ${ }^{12}$

\section{LONG-TERM TRENDS IN HEIGHTS}

Figure 1 compares the present estimates of French national median height (or mean, under the maintained assumption of normality) with estimates for other countries based on similar sources. ${ }^{13}$ For France, the overall impression is one of slow but steady increase in height from 1815 to 1913 . On closer inspection one might detect slightly faster growth at the beginning and the end of the period, with a period of near-stability from 1880 to 1900 . The rate of growth was substantially

Austria-Hungary (Komlos, Nutrition and Economic Development), and for virtually all the countries compiled by Chamla, "L'accroissement de la stature," and by Floud, "The Heights of Europeans since 1750."

${ }^{11}$ Wachter, "Graphical Estimation of Military Heights"; Wachter and Trussell, "Estimating Historical Heights"; and Floud, Wachter, and Gregory, Height, Health and History.

${ }^{12}$ I suspect this is the explanation for the (very slight) fall in the heights of students at the Ecole Polytechnique between 1800 and 1850 observed by Sutter, "L'évolution de la taille," and recently analyzed in greater detail by Komlos, "Nutritional Status." Polytechniciens were about 50 millimeters (one standard deviation of the population) taller than conscripts of similar ages in the nineteenth century. The decline narrowed the gap to $\mathbf{4 0}$ millimeters.

${ }^{13}$ The French estimates for 1815 to 1914 , although based on essentially the same sources used by van Meerten, "Développement économique et stature," differ from his prior to 1868 because of improvements in the method of estimation, which are described in my data appendix. The estimates after 1910 are from Chamla, "L'accroissement de la stature," based on samples of individual data from each department. His estimates for 1880, 1890, 1900, and 1910 agree closely with my own. 


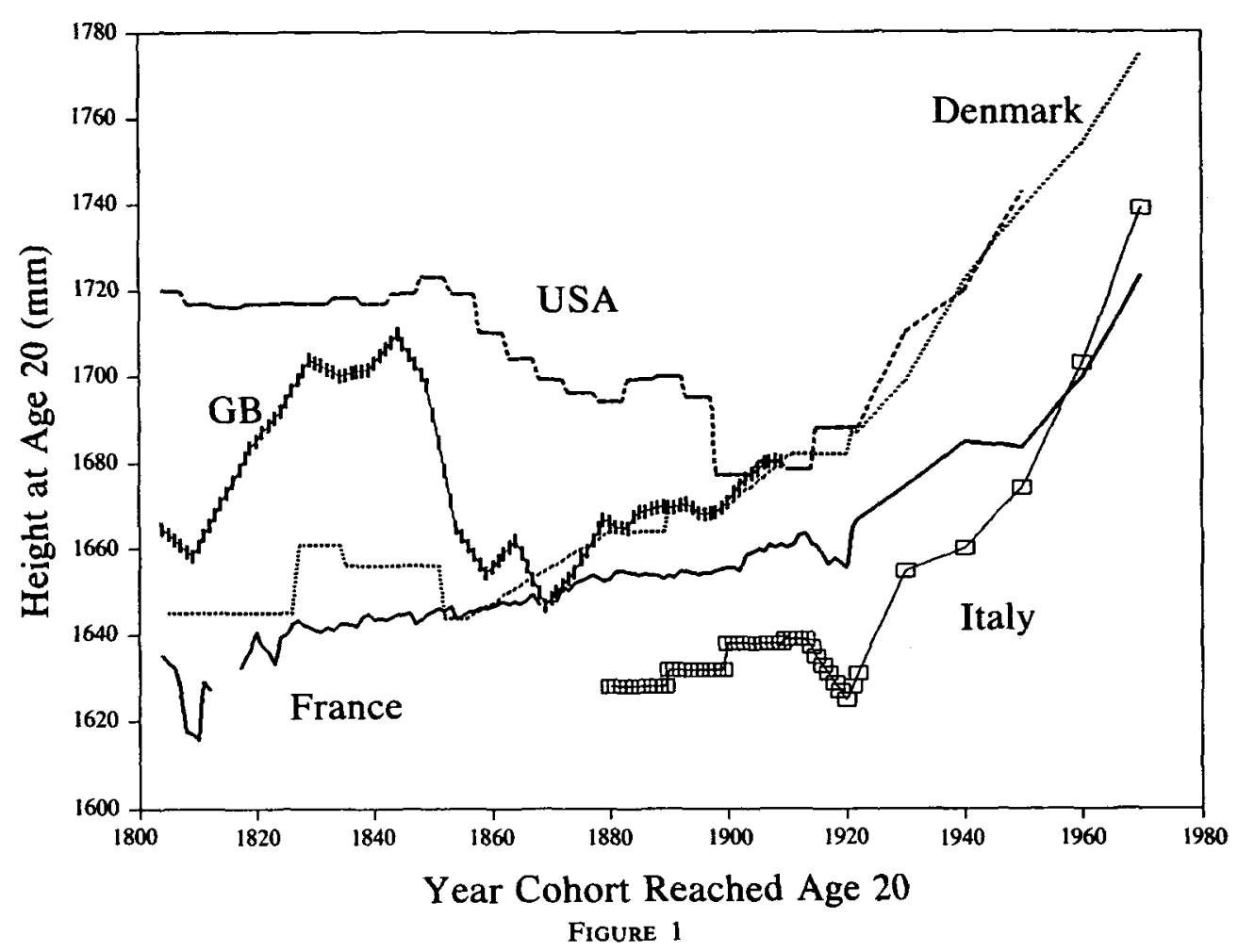

HEIGHTS IN SEVERAL COUNTRIES, 1800-1913

Note: Insofar as possible, the data refer to the mean heights of 20-year-old men at the date they reached age 20.

Sources: For France, 1804-1922: present estimates (see text and author's data appendix); for France, 1930-1970: Chamla, "L'accroissement de la stature"; for England: Floud, Wachter, and Gregory, Height, Health and History, table 4.1; for Denmark and Italy: Floud, "The Heights of Europeans since 1750"; for the United States: Steckel, "Stature and Living Standards."

faster in the twentieth century, but was punctuated by more severe setbacks in the two world wars.

Figure 1 includes my estimates for the period of the First Empire, 1803 to 1812 . I made some adjustments to render them comparable with the later data. ${ }^{14}$ They are based on archival records of conscription similar to the later data and so avoid the problem of selection present in Houdaille's estimates of the heights of active soldiers during the same period. ${ }^{15}$ Nevertheless, the flexibility of the lower recruitment rules at a time of mass mobilization dictates caution in interpretation. The sharp

\footnotetext{
${ }^{14}$ Records could be found for only 30 of the 86 departments. After comparing this subset with the whole in the early nineteenth century, I augmented the mean of the subsample by 4 millimeters to make it comparable with the national totals.

is Houdaille, "La taille des français," found a median of 1,658 millimeters, but stressed that these soldiers were likely to be taller than randomly drawn conscripts at age 20 (because the active soldiers were older, and because taller men were likely to stay in the army longer). The adjusted median for $1804 / 05$ in the conscript records was about 1,634 millimeters.
} 
fall in heights of 1805 to 1809 coincided precisely with the return to a wartime footing after the collapse of the Peace of Amiens. Napoleon's manpower needs led to the recruitment of younger and less fit conscripts, and I have not attempted to correct the data for this. On the other hand, the fact that the heights of the classes of 1804/05 and 1810/11 were on a par with those of the early years of the Restoration (at about 1,630 to 1,635 millimeters) suggests that there was probably little trend in heights over the first 20 years of the nineteenth century.

It is even more difficult to know the course of heights before 1805-that is, for cohorts born before 1785 . As the fertility transition began in the 1790s, it would be of great interest to compare cohorts born and raised before 1789 with those that came later. Unfortunately, no reliable data exist for the general population, and the few indications that are available are sufficiently different as to leave open almost any possible trend. If we work from the heights of active soldiers, even after accounting for the absolute minimum standard of five pieds (about 1,625 millimeters, or five feet, four inches on the English scale), we arrive at an estimate of perhaps 1,680 millimeters-much higher than after the Revolution. ${ }^{16}$ But as the army preferred taller soldiers for prestigious services, this is not a representative sample, and it has the tell-tale narrow variance of a selected sample. Working from the opposite direction-the fraction of population left out of the army-we get an estimate of about 1,605 millimeters, much shorter than after the Revolution. ${ }^{17}$

French height history appears remarkably calm and stable by comparison with the others. The country with the most similar time profile is Denmark, where men were slightly taller overall but where the pace of growth was slower in the first half of the nineteenth century. Danish heights advanced more rapidly in the late-nineteenth and twentieth centuries. England presents a bizarre picture. From levels somewhat above the French and Danish before 1815, English heights vaulted by 1840 to levels above the Americans and not seen anywhere else in Europe until after World War I. They then collapsed to equality with the French, around 1870, and followed the Danish path thereafter. Unfortunately, there are no data for southern Europe before 1880. At the end of the nineteenth century, France was squarely in the middle between taller (northern) and shorter (southern) Europe-no surprise for a country ranging from the English Channel to the Mediterranean.

Doubts about the quality of data from other countries permit only speculative conclusions from the international comparisons. France

\footnotetext{
${ }^{16}$ Corvisier, L'armée française, p. 649, provides some data, but cautions readers about the nonrepresentativeness of the sample (pp. 643-44).

${ }^{17}$ Moheau, cited in Corvisier, L'armée française, p. 643, gave estimates of the population needed to provide a given quantity of soldiers of given heights. Details of the estimation of the implied mean height from this information is available in the data appendix.
} 
may have made modest gains on the rest of Europe during the first phase of industrialization to 1850 or 1870 , when other European countries were facing more severe Malthusian pressures. ${ }^{18}$ In the latter part of the nineteenth century France appears to have done no better than other countries. By that time, of course, the rest of Europe was entering the fertility transition, too, and France was cutting itself off from the benefits of lower world food prices by pursuing a policy of protectionism. The twentieth-century acceleration in heights seen in France was shared if not surpassed by its neighbors.

\section{INCOMES, FOOD CONSUMPTION, AND HEIGHTS}

As van Meerten has demonstrated, there was a close correspondence between the movement of real GNP per capita and heights in France. ${ }^{19}$ Leaving aside the plausibility (and identifiability) of the detailed distributed-lag model van Meerten estimated based on prior specifications by Brinkman, Drukker, and Slot, it is clear from Figure 2 that the correspondence of the two series is more than simply a shared upward trend. Like heights, GNP per capita grew slowly in the nineteenth century and much more rapidly in the twentieth.

When we seek to decompose real GNP into the components that presumably matter most for heights, we discover a paradox. Figure 3 shows the evolution of nutrient consumption in France. ${ }^{20}$ Most of the increases in calories and proteins came in the nineteenth century, not in the twentieth. ${ }^{21}$ Only fat consumption shared the pattern of timing shown by heights and by real GNP per capita.

Thus, we have a two-part puzzle that has been masked by an apparent close correlation of real GNP per capita and heights. GNP did not translate directly into mean calorie intake, and mean calorie intake did not translate directly into improved heights. In the nineteenth century, calorie intake rose quickly relative to GNP, whereas heights improved slowly. In the twentieth century, GNP growth accelerated whereas

${ }^{18}$ For example, Sandberg and Steckel, "Overpopulation and Malnutrition Rediscovered," claims that heights declined in mid-nineteenth-century Sweden because of overpopulation.

19 van Meerten, "Développement économique et stature."

${ }^{20}$ Nutrient consumption has been estimated using the national food balance sheet methods of the OECD: estimating the volume of production of different agricultural products and then adjusting for net exports, use as animal food, use as intermediate inputs, and losses in conversion to edible form. The data for 1781 to 1938 are from Toutain, "La consommation alimentaire"; postwar data are from the OECD. To ensure the consistency of the two series, I took the quantity estimates for various food groups and applied the same nutrient composition tables throughout. I also added in the consumption of alcoholic beverages, which accounted for a substantial share of calories.

${ }^{21}$ Morineau, "Révolution agricole," and Grantham, "Divisions of Labour," suggest that Toutain underestimated the consumption (and production) of cereals and their substitutes prior to midcentury and offer evidence based on numerous qualitative sources that the ration of bread (or substitutes) per capita was at a level of about 1,900 calories per day, from at least the early eighteenth century. According to Toutain, this level was reached around 1840. If one follows his critics, the profile of nutrient consumption would show little growth from 1781 to 1840 . 


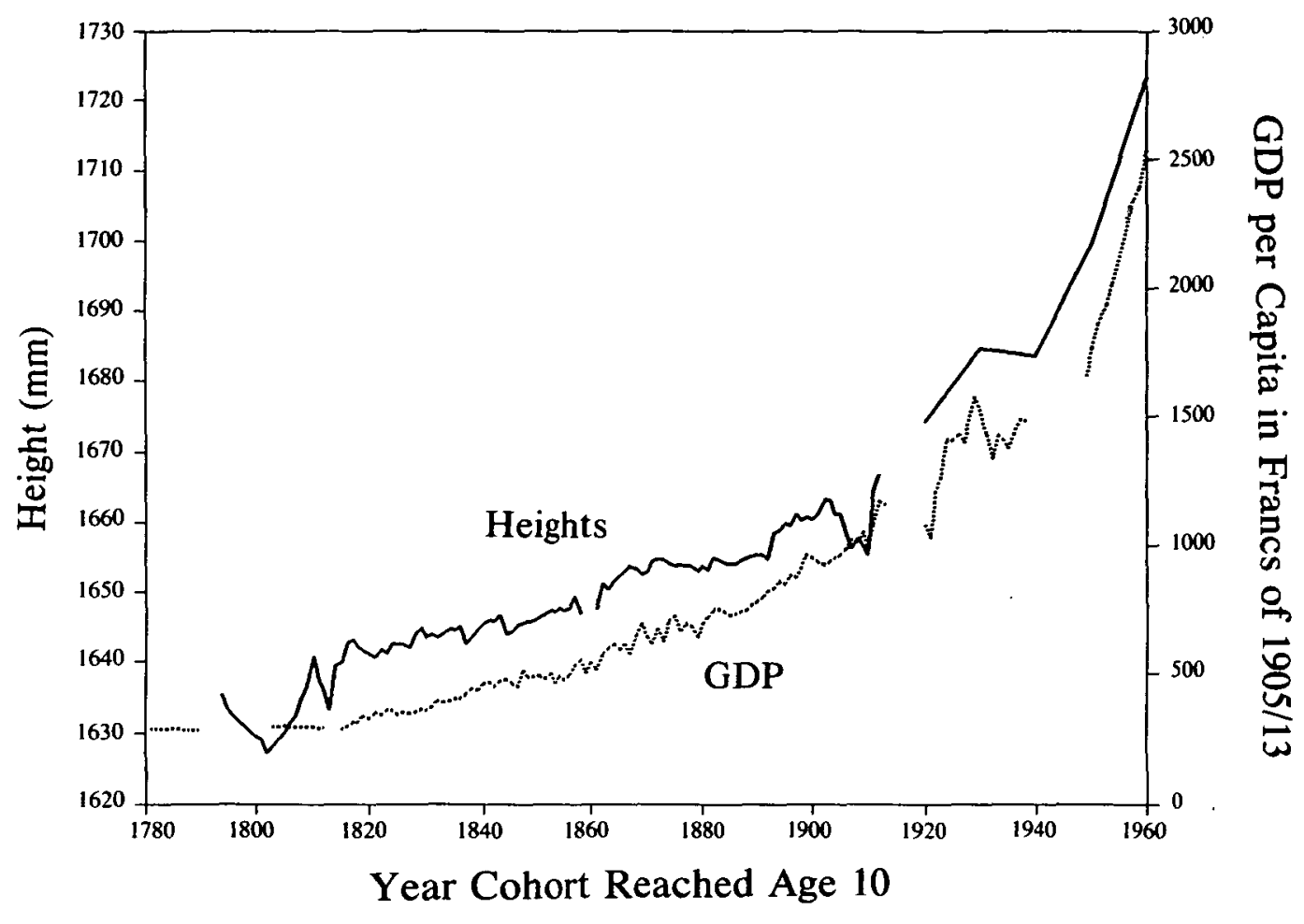

FIGURE 2

HEIGHTS AND REAL GDP PER CAPITA IN FRANCE, 1780-1960

Sources: Toutain, "Le produit intérieur brut"; and present estimates.

calories remained stable and heights grew rapidly. To resolve this puzzle we must reintegrate the other determinants of children's net nutritional status: disease, work demands, and the intrafamily distribution of resources.

We do not have direct observations on the extent of morbidity (that is, the incidence of nonfatal disease), which is what matters for the heights of survivors. We do have evidence on mortality rates, however. The timing of changes in infant and child mortality provides some support for the role of disease. The proportions surviving to age 20 improved in two rapid bursts: from less than 50 percent before 1790 to about 65 percent in 1840, and from less than 70 percent in 1890 to more than 85 percent by 1940 . We do not know whether heights followed life expectancy in the first burst of improvement, but they clearly did in the second. The timing of mortality change offers a plausible explanation for the timing of change in heights, if mortality was closely linked to morbidity and if morbidity levied a strong "tax" on caloric intake. This can help resolve the second part of the puzzle. There is reason to doubt, however, that mortality (or morbidity) was determined simply by 


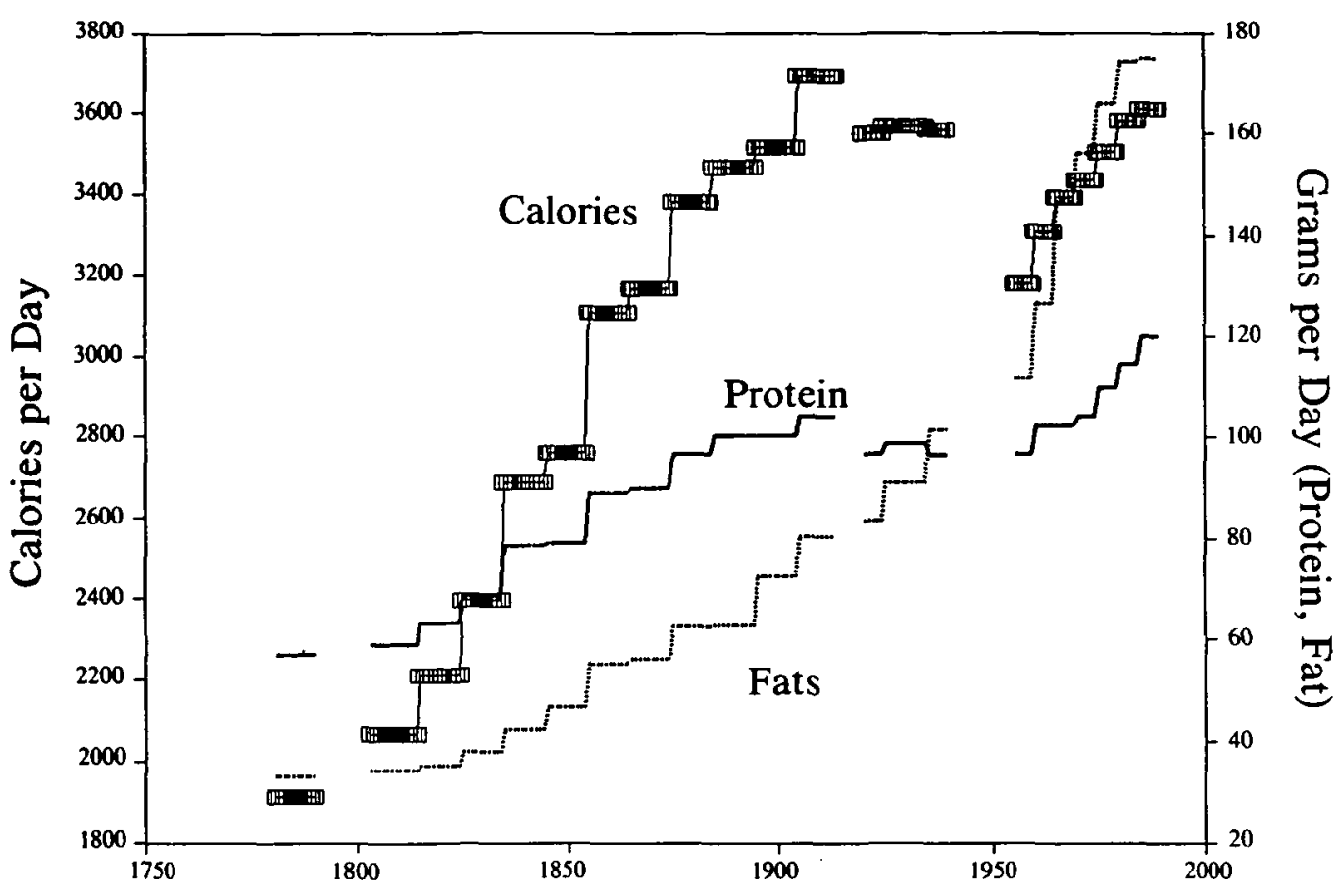

FiguRe 3

NUTRIENT CONSUMPTION PER CAPITA IN FRANCE, 1780-1990

Sources: Toutain, "La consommation alimentaire"; and OECD, Food Consumption Statistics.

income. ${ }^{22}$ We should therefore consider other paths by which GNP may have influenced heights.

Not surprisingly, the acceleration of GNP growth at the end of the nineteenth century went hand in hand with a dramatic change in consumption patterns that could deservedly be called a consumer revolution. Table 1 summarizes some key elements. Average hours of work began to fall after 1890 , and the decline of agriculture accelerated. The combination of increased leisure and more sedentary work reduced the calorie demands of working-age adults. In the nineteenth century, consumption of all types of food increased, with a modest shift toward more expensive sources of calories that was very consistent with the structure of food demand estimated from an 1852 cross section. ${ }^{23}$ After

22 McKeown, The Modern Rise of Population, has been the leading proponent of the importance of food supplies. His views have been taken up and expanded on by Robert Fogel, "Second Thoughts on the European Escape from Hunger," and "New Sources and New Techniques." On the other side are those like Johannson and Mosk, "Exposure, Resistance, and Life Expectancy," who find specific evidence of the contribution of (urban) public health investments, and those like Preston, Mortality Patterns, who find that income explains very little of mortality variation within a given state of medical knowledge and technology.

${ }_{23}$ Postel-Vinay and Robin, "Eating, Working, and Saving," estimated expenditure elasticities of various food categories that predict reasonably well the nineteenth-century aggregate trends. 
TABLE 1

THE CONSUMER REVOLUTION

\begin{tabular}{ccccc}
\hline \hline & $\begin{array}{c}\text { Percentage of } \\
\text { Male Labor Force } \\
\text { in Agriculture }\end{array}$ & $\begin{array}{c}\text { Annual } \\
\text { Labor } \\
\text { Hear }\end{array}$ & $\begin{array}{c}\text { Percentage of } \\
\text { Calories from } \\
\text { Basic Starches }\end{array}$ & $\begin{array}{c}\text { Labor Force } \\
\text { Participation Rate } \\
\text { at Ages 10 to 24 }\end{array}$ \\
\hline 1810 & 116.4 & 100.7 & 95.5 & - \\
1850 & 100.0 & 100.0 & 100.0 & - \\
1890 & 80.0 & 98.0 & 97.5 & 100.0 \\
1930 & 56.4 & 72.9 & 70.7 & 108.2 \\
1970 & 21.8 & 64.7 & 47.6 & 64.2 \\
\hline
\end{tabular}

Note: $1850=100$.

Sources: Marchand and Thélot, Deux siècles de travail; Toutain, "La consommation alimentaire"; and OECD, Food Consumption Statistics.

1900 , that structure changed dramatically, as further income growth was accompanied by an absolute decline in the consumption of basic foods (bread and other starches) capable of providing calories at a low (and declining) relative price. The real revolution in human capital accumulation, however-increasing schooling at the expense of labor force participation-may not have begun until the interwar years.

This consumer revolution helps explain why child nutrition apparently improved in the twentieth century even though per capita food consumption changed little, but it does not explain why heights grew slowly in the nineteenth century when calories were rising rapidly. Further research in energy accounting is needed to determine the adequacy of adult diets in the early nineteenth century to meet the demands of full-effort, full-time work schedules. Crude calculations suggest that they were not adequate, so much of the nineteenth-century nutritional gains went to feed adults, to enhance their productivity. ${ }^{24}$ This allocation may have been a free consumption choice by parents, or it may have been to some extent imposed on them. When productivity depends on nutrition, employers have an incentive to find ways to improve the nutrition of their workers. In European agriculture, this was typically done by feeding workers on the job. Future research should also address the question of whether these labor market solutions effectively constrained household consumption allocations.

\section{STATISTICAL TESTS}

The speculations advanced in the previous section would be difficult to test with aggregate time-series data, because there were few changes in trends of the key variables, and all were highly collinear. We may be

\footnotetext{
${ }^{24}$ John Strauss, "Does Better Nutrition Raise Labor Productivity?" estimated that more calories meant higher productivity in agriculture up to a level of about 4,500 calories per adult equivalent. Given the French age distribution, there were about .76 adult equivalents per person, so the per capita calorie peak of 3,500 calories corresponds very closely to the point at which Strauss found additional calories to have no additional productivity benefits.
} 
able to do better using a combination of cross-section and time-series observations in which changes over time and differences between regions are on the same footing in the analysis of variance in dependent and independent variables. This requires that each variable be measured in units that are comparable over both space and time, which limits us for the moment to a few simple variables and to the period before 1914 . Nevertheless, we can test whether the disease environment, as represented by local mortality, had an independent effect on heights after controlling for income. We can also test whether there was a significant substitution between quantity and quality of children.

I took complete cross sections of height data by department, at intervals of about ten years, for a total of nine cross sections of 90 departments. Of these, 81 were in continuous observation, yielding a total sample size of $729 .{ }^{25}$ Each of the nine cross sections corresponds to a single year-of-birth cohort. In matching the height data to other variables, I chose values from the years around the cohort's tenth birthday, except for literacy. ${ }^{26}$

I also took account of well-known persistent regional differences in heights: men were tallest in the Northeast and shortest in the Southwest. Some scholars have sought to explain this as a result of economic differences; the anthropologists of the nineteenth century saw in it the mixing of two distinct races of ancient origin. ${ }^{27}$ It might also represent persistent cultural differences in the way children were raised. Without insisting on any particular interpretation of the regional effect, it is important to see whether it retains independent predictive power after accounting for the variables thought to produce heights. Brief experimentation showed that a simple continuous variable for "Northeast," calculated as the sum of degrees latitude and degrees longitude of the department, worked as well as any alternative specification.

Table 2 shows the results of five different reduced-form specifications of the determinants of heights. The connection between fertility and heights is indirect. Assuming that there were some relative (shadow) prices observable to parents that influenced their allocations of resources between their own consumption and investments in child quality, and that the observed variables do not fully capture variations

\footnotetext{
${ }^{25}$ The recruitment years in the panel are 1840, 1846, 1856, 1866, 1875, 1886, 1895, 1905, and 1911. Height distributions by department were taken from the annual volumes of the Compte-rendu sur le recrutement de l'armée, except for 1875 and 1895, which were taken from the Annuaire Statistique.

${ }^{26}$ The variables are real wages, estimated as the ratio of nominal daily wages of men in agriculture to the price of wheat; marital fertility, estimated by the Princeton index Ig; crude death rates; urbanization, measured as the percentage living in places of 2,000 or more; and literacy, measured as the percentage of conscripts able to sign their names.

27 Villermé, "Mémoire sur la taille," and Aron, Dumont, and Le Roy Ladurie, L'anthropologie du conscrit, tend toward the materialist view, whereas Broca, Mémoires d'anthropologie, emphasized the racial.
} 
TABLE 2

THE DETERMINANTS OF MALE HEIGHTS BY DEPARTMENT, 1840-1911

\begin{tabular}{|c|c|c|c|c|c|}
\hline $\begin{array}{l}\text { Independent } \\
\text { Variable }\end{array}$ & 1 & 2 & 3 & 4 & 5 \\
\hline Constant & $\begin{array}{c}1677^{* * *} \\
(1.9)\end{array}$ & $\begin{array}{l}1202^{* * *} \\
(34.8)\end{array}$ & $\begin{array}{l}1595^{* * * *} \\
(54.0)\end{array}$ & $\begin{array}{l}1653^{* * *} \\
(53.3)\end{array}$ & $\begin{array}{l}1826^{* * *} \\
(55.1)\end{array}$ \\
\hline Marital fertility $(I g)$ & $\begin{array}{c}-52.29^{* * *} \\
(3.65)\end{array}$ & $\begin{array}{c}-30.81^{* * *} \\
(3.26)\end{array}$ & $\begin{array}{c}-14.75^{* * *} \\
(3.51)\end{array}$ & $\begin{array}{c}-12.30^{* * *} \\
(3.43)\end{array}$ & $\begin{array}{c}-10.03^{* * *} \\
(3.29)\end{array}$ \\
\hline Year of recruitment & & $\begin{array}{l}0.182^{* * *} \\
(0.018)\end{array}$ & $\begin{array}{c}-0.030 \\
(0.029)\end{array}$ & $\begin{array}{c}-0.058^{*} \\
(0.028)\end{array}$ & $\begin{array}{c}-0.149^{* * *} \\
(0.029)\end{array}$ \\
\hline Northeast & & $\begin{array}{l}2.536^{* * *} \\
(0.114)\end{array}$ & $\begin{array}{l}2.109^{* * *} \\
(0.125)\end{array}$ & $\begin{array}{l}2.073^{* * *} \\
(0.122)\end{array}$ & $\begin{array}{l}1.682^{* * *} \\
(0.126)\end{array}$ \\
\hline Real wage (log) & & & $\begin{array}{l}15.38^{* * *} \\
(2.07)\end{array}$ & $\begin{array}{l}13.83^{* * *} \\
(2.03)\end{array}$ & $\begin{array}{l}10.66^{* * *} \\
(1.98)\end{array}$ \\
\hline Crude death rate & & & $\begin{array}{c}-0.765^{* * *} \\
(0.134)\end{array}$ & $\begin{array}{c}-1.054^{* * *} \\
(0.138)\end{array}$ & $\begin{array}{c}-0.895^{* * *} \\
(0.133)\end{array}$ \\
\hline Urbanization & & & & $\begin{array}{l}17.60^{* * *} \\
(2.75)\end{array}$ & $\begin{array}{l}16.86^{* * * *} \\
(2.63)\end{array}$ \\
\hline $\begin{array}{l}\text { Literacy of } \\
\text { conscripts }\end{array}$ & & & & & $\begin{array}{c}24.75^{* * *} \\
(2.9)\end{array}$ \\
\hline$R$-squared & .22 & .57 & .62 & .64 & .67 \\
\hline
\end{tabular}

* = Significant at the 5 percent level.

*** $=$ Significant at the 0.1 percent level.

Notes: The dependent variable is the median height of the cohort of 20-year-old men in a given department in a given year. Data sources and estimation methods are described in the text and a data appendix. The total sample size is 81 departments in 9 cohorts, or 729 observations. Regressions were OLS; standard errors are shown in parentheses.

in the relative prices, then the inclusion of fertility (a jointly determined variable) as a "determinant" of heights amounts to assuming that fertility contains additional information about the unobserved relative prices of child quantity and quality.

In the first model, marital fertility $(I g)$ had a strong negative effect on heights and by itself explained 22 percent of the variance in heights. A typical fertility transition would be a fall in $I g$ from .8 to .3 , or a drop of .5. That is what France accomplished from 1790 to 1911. With a coefficient of -52 , a fall of .5 would add about 25 millimeters or one English inch to height-about the full magnitude of the nineteenthcentury French gain. Model 2 adds controls for time trend and regional patterns of heights. They accounted for a lot of the variance and reduced the magnitude of the coefficient on $I g$, but it remained highly significant.

Model 3 adds real wages and the crude death rate. Mortality had an apparently independent negative influence on heights, whereas real wages had the expected positive impact. With these variables included, the time trend dropped to nearly zero, indicating that the combination of fertility, mortality, and income can fully account for the upward trend in heights. By contrast, the (time-invariant) regional effect (Northeast 
versus Southwest) remained very strong. The coefficient on $I g$ fell again, but still remained significant.

Model 4 adds urbanization, which had a strong positive effect on heights. Its inclusion did little to change the other coefficients, except for making the effect of crude death rates even more strongly negative. This suggests that urbanization was a two-edged sword, with only one edge left to its own coefficient. On the one hand, urbanization enhanced child nutrition by shifting more of the population into higher-paying and less calorie-demanding occupations (an effect not accounted for by real wages in the agricultural sector alone, and so picked up by the urbanization coefficient). On the other it "taxed" nutrients by raising the incidence of disease (an effect already captured in this model by the crude death rate).$^{28}$ It is also possible that urbanization encouraged investments in children.

Model 5 adds the literacy rates of the same conscripts whose heights were measured in the dependent variable. One would expect these jointly determined aspects of human capital investment to be strongly correlated, and they were. Because mortality and fertility were included in the model, literacy's effect cannot be attributed to an indirect effect through better health or access to contraception. The most plausible interpretation is that investments in children in the form of literacy were complementary to investments in better nutrition. This could be as simple as the contrast between sending young children out to do hard physical work and sending them to school, or it may have involved more complex redistributions of nutritional and health resources.

\section{CONCLUSIONS}

Although nutritional intake is undoubtedly of fundamental importance to human growth, the historical variations over time and space in the amounts of food consumed per capita appear to have accounted for only a small share of the secular increase and regional divergences of heights in France. This can be attributed to two factors: the independent role of disease as a claim on calories, and the allocation of resources between children and adults.

In the nineteenth century, heights and life expectancy improved the hard way: by expanding food consumption to improve resistance to disease and to compensate in part for morbidity's demands on calories. In the twentieth-century context of a well-fed population, advances in public health and medical technology then pushed heights and life expectancy ahead at an accelerated pace. Another implication of the results is that heights can be highly correlated with life expectancy not

\footnotetext{
28 Johannson and Mosk, "Exposure, Resistance, and Life Expectancy,” found similar offsetting influences of urbanization on mortality in Japan, and noted that the advance of public health allowed the positive effects to increase over time.
} 
because increased food intake was driving improvements in both, but rather because an exogenous reduction in the incidence of disease simultaneously lowered mortality rates and reduced the claims on calories, allowing heights to increase.

In early industrialization, the share of total nutritional resources devoted to children competed with the benefits of enhanced labor productivity from better-fed adults until caloric intakes reached the limit of this process at the end of the nineteenth century. At that point a transformation of consumption patterns redirected resources toward children.

The early fertility transition in France had some beneficial influence on heights, though probably less than modern population planners might hope for. It certainly did not place France at the top of the European spectrum of heights; at best it held off some of the deterioration apparently experienced elsewhere in the nineteenth century. As an indicator of possible changes in the relative returns to investments in child quality, marital fertility decline showed a small but significant influence on heights. This is, of course, the most limited possible path of influence. To the extent that the other variables such as real wages, literacy, and urbanization proxied for the determinants of intrahousehold distribution, there was less unobserved variance in such determinants left to be proxied for by marital fertility. And to the extent that fertility decline operated through the macroeconomy to keep real wages up, or through reduced population density to keep disease exposure rates down, some part of the large role assigned to these factors must also be credited to the fertility decline.

\section{REFERENCES}

Aron, Jean-Paul, Paul Dumont, and Emmanuel Le Roy Ladurie, Anthropologie du conscrit français d'après les comptes numériques et sommaires du recrutement de l'armée (1819-1826) (Paris, 1972).

Behrman, Jere, and Anil Deolalikar, "Health and Nutrition," in Hollis Chenery and T. N. Srinivasan, eds., Handbook of Development Economics (Amsterdam, 1988), vol. 1, pp. 631-711.

Brinkman, Henk-Jan, J. W. Drukker, and B. Slot, "Height and Income: A New Method for the Estimation of Historical National Income Series," Explorations in Economic History, 25 (Mar. 1988), pp. 227-64.

Broca, Paul, Mémoires d'anthropologie (Paris, 1871).

Chamla, Marie-Claude, "L'accroissement de la stature en France de 1880 à 1960: Comparaison avec les pays d'Europe occidentale," Bulletins et Mémoires de la Société d'Anthropologie de Paris, 6, 11th série (Apr.-June 1964), pp. 201-78.

Corvisier, André, L'armée française de la fin du 17e siècle au Ministère Choiseul (Paris, 1964). 
Floud, Roderick, "The Heights of Europeans since 1750: A New Source for European Economic History"' (NBER Working Paper No. 1318, 1984).

Floud, Roderick, Kenneth Wachter, and Annabel Gregory, Height, Health and History: Nutritional Status in the United Kingdom, 1750-1980 (Cambridge, 1990).

Fogel, Robert W., "Nutrition and the Decline in Mortality since 1700: Some Preliminary Findings," in Stanley L. Engerman and Robert E. Gallman, eds., Long-Term Factors in American Economic Growth (Chicago, 1986), pp. 439-555.

Fogel, Robert W., "New Sources and New Techniques for the Study of Secular Trends in Nutritional Status, Health, Mortality, and the Process of Aging" (NBER Historical Working Paper No. 26, 1991).

Fogel, Robert W., "Second Thoughts on the European Escape from Hunger: Famines, Chronic Malnutrition, and Mortality," in S. R. Osmani, ed., Nutrition and Poverty (Oxford, forthcoming).

France, Ministère de la Guerre, Compte-rendu sur le recrutement de l'armée (Paris, various years).

France, Statistique Générale, Annuaire Statistique de la France (Paris, various years). Grantham, George, "Divisions of Labour: Agricultural Productivity and Occupational Specialization in Pre-Industrial France," Economic History Review (forthcoming).

Houdaille, Jacques, "La taille des français au début du XIXe siècle," Population, 25 (Nov.-Dec. 1970), pp. 1297-98.

Johannson, Sheila Ryan, and Carl Mosk, "Exposure, Resistance and Life Expectancy: Disease and Death during the Economic Development of Japan, 1900-1960," Population Studies, 41 (Jan. 1987), pp. 207-35.

Komlos, John, Nutrition and Economic Development in the Eighteenth-Century Habsburg Monarchy: An Anthropometric History (Princeton, 1989).

Komlos, John, "The Nutritional Status of the Students of the École Polytechnique, 1770-1869'" (Photocopy, University of Pittsburgh Department of History, 1992).

McKeown, Thomas, The Modern Rise of Population (New York, 1976).

Marchand, Olivier, and Claude Thélot, Deux siecles de travail en France (Paris, 1991).

Mokyr, Joel, "Economics, History, and Human Biology," Economic Development and Cultural Change, 36 (Apr. 1988), pp. 559-64.

Morineau, Michel, "Révolution agricole, révolution alimentaire, révolution démographique," Annales de Démographie Historique (1974), pp. 335-74.

OECD, Food Consumption Statistics, 1955-1973 (Paris, 1975).

Postel-Vinay, Gilles, and Jean-Marc Robin, "Eating, Working, and Saving in an Unstable World: Consumers in Nineteenth-Century France," Economic History Review, 45 (Aug. 1992), pp. 494-513.

Preston, Samuel H., Mortality Patterns in National Populations (New York, 1976).

Rosenzweig, Mark, and T. Paul Schultz, "Market Opportunities, Genetic Endowments and Intrafamily Resource Distribution: Child Survival in Rural India," American Economic Review, 72 (Sept. 1982), pp. 803-15.

Sandberg, Lars, and Richard Steckel, "Overpopulation and Malnutrition Rediscovered: Hard Times in 19th-Century Sweden," Explorations in Economic History, 25 (Jan. 1988), pp. 1-19.

Steckel, Richard, "Height and Per Capita Income," Historical Methods, 16 (Jan. 1983), pp. 1-7.

Steckel, Richard, "Stature and Living Standards in the United States" (NBER Historical Working Paper No. 24, 1991).

Strauss, John, "Does Better Nutrition Raise Farm Productivity?"' Journal of Political Economy, 94 (Mar. 1986), pp. 297-320.

Sutter, Jean, René Izac, and Tran Ngoc Toan, 'L'évolution de la taille des polytechniciens, 1901-1954,” Population, 3 (July 1958), pp. 373-406. 
Tanner, J. M., Fetus Into Man: Physical Growth from Conception to Maturity (London, 1978).

Tanner, J. M., A History of the Study of Human Growth (Cambridge, 1981).

Toutain, Jean-Claude, "La consommation alimentaire en France de 1789 à 1964," Économies et Sociétés, 5 (Nov. 1971), pp. 1913-2049.

Toutain, Jean-Claude, "Le produit intérieur brut de la France de 1789 à 1982," Économies et Sociétés, Série AF: Histoire quantitative de l'économie française, 21 (May 1987), pp. 49-237.

van Meerten, Michiel Alexander, "Développement économique et stature en France, XIXe-XXe siècles," Annales: ESC, 45 (May-June 1990), pp. 755-77.

Villermé, Louis R., "Mémoire sur la taille de l'homme en France," Annales d'hygiène publique, 1 (1829), pp. 551-59.

Wachter, Kenneth W., "Graphical Estimation of Military Heights," Historical Methods, 14 (Winter 1981), pp. 31-42.

Wachter, Kenneth, and James Trussell, "Estimating Historical Heights," Journal of the American Statistical Association, 77 (June 1982), pp. 279-93.

Weir, David R., "Two Approaches to the Fertility Transition: Family Reconstitution and Population Reconstruction," in David Reher and Roger Schofield, eds., New Methods of Historical Demography (Liège, Belgium, 1993). 